University of Nebraska - Lincoln

DigitalCommons@University of Nebraska - Lincoln

Agronomy \& Horticulture - Faculty Publications

Agronomy and Horticulture Department

2020

\title{
Relating four-day soil respiration to corn nitrogen fertilizer needs across 49 U.S. Midwest fields
}

G. M. Bean

Soil Health Institute, Morrisville, NC, gmacbean89@gmail.com

Newell R. Kitchen

USDA-ARS, kitchenn@missouri.edu

Kristen S. Veum

USDA, Agricultural Research Service, kristen.veum@usda.gov

James J. Camberato

Purdue University, jcambera@purdue.edu

Richard Ferguson

University of Nebraska-Lincoln, rferguson1@unl.edu

See next page for additional authors

Follow this and additional works at: https://digitalcommons.unl.edu/agronomyfacpub

Part of the Agricultural Science Commons, Agriculture Commons, Agronomy and Crop Sciences Commons, Botany Commons, Horticulture Commons, Other Plant Sciences Commons, and the Plant Biology Commons

Bean, G. M.; Kitchen, Newell R.; Veum, Kristen S.; Camberato, James J.; Ferguson, Richard; Fernandez, Fabian G.; Franzen, David W.; Laboski, Carrie A.M.; Nafziger, Emerson; Sawyer, John E.; and Yost, Matt, "Relating four-day soil respiration to corn nitrogen fertilizer needs across 49 U.S. Midwest fields" (2020). Agronomy \& Horticulture -- Faculty Publications. 1444.

https://digitalcommons.unl.edu/agronomyfacpub/1444

This Article is brought to you for free and open access by the Agronomy and Horticulture Department at DigitalCommons@University of Nebraska - Lincoln. It has been accepted for inclusion in Agronomy \& Horticulture -Faculty Publications by an authorized administrator of DigitalCommons@University of Nebraska - Lincoln. 


\section{Authors}

G. M. Bean, Newell R. Kitchen, Kristen S. Veum, James J. Camberato, Richard Ferguson, Fabian G.

Fernandez, David W. Franzen, Carrie A.M. Laboski, Emerson Nafziger, John E. Sawyer, and Matt Yost 


\title{
Relating four-day soil respiration to corn nitrogen fertilizer needs across 49 U.S. Midwest fields
}

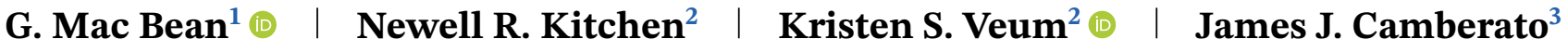 \\ Richard B. Ferguson ${ }^{4}$ \\ Carrie A.M. Laboski ${ }^{7}$ \\ Fabian G. Fernandez $z^{5}$ () \\ David W. Franzen ${ }^{6}$ \\ Emerson D. Nafziger ${ }^{8}$

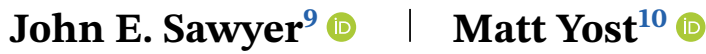

\footnotetext{
${ }^{1}$ Soil Health Institute, 2803 Slater Road, Suite 115, Morrisville, NC, 27560 USA

${ }^{2}$ USDA-ARS, 243 Agricultural

Engineering Building, Columbia, MO, 65211 USA

${ }^{3}$ Purdue University College of Agriculture, Agronomy Dept., 915 W. State Street, West Lafayette, IN, 47907 USA

${ }^{4}$ Univ. of Nebraska, Dept. of Agronomy and Horticulture, 202 Keim Hall, Lincoln, NE, 68583 USA

${ }^{5}$ Univ. of Minnesota, Dept. of Soil, Water, and Climate, S233 Soil Science Building, St. Paul, MN, 55108 USA

${ }^{6}$ North Dakota State Univ., Soil Science Dept, 7180, PO Box 6050, Fargo, ND, 58108 USA

${ }^{7}$ Univ. of Wisconsin-Madison, Dept. of Soil Science, 1525 Observatory Dr., Madison, WI, 53706 USA

${ }^{8}$ Univ. of Illinois, Dept. of Crop Sciences (emeritus), Urbana, IL, 61801 USA

${ }^{9}$ Iowa State Univ., Dept. of Agronomy, Ames, IA, 50011 USA

${ }^{10}$ Utah State Univ., Plants, Soils, Climate Dept., 4820 Old Main Hill, Logan, UT, 84322 USA
}

Correspondence

G. Mac Bean, 2412 Kays Pointe Dr.,

Columbia, MO, USA.

Email:gmacbean89@gmail.com

Funding information

Corteva Agriscience

\begin{abstract}
Soil microbes drive biological functions that mediate chemical and physical processes necessary for plants to sustain growth. Laboratory soil respiration has been proposed as one universal soil health indicator representing these functions, potentially informing crop and soil management decisions. Research is needed to test the premise that soil respiration is helpful for profitable in-season nitrogen $(\mathrm{N})$ rate management decisions in corn (Zea mays L.). The objective of this research was two-fold: (i) determine if the amount of $\mathrm{N}$ applied at the time of planting effected soil respiration, and (ii) evaluate the relationship of soil respiration to corn yield response to fertilizer $\mathrm{N}$ application. A total of 49 $\mathrm{N}$ response trials were conducted across eight states over three growing seasons (2014-2016). The 4-day Comprehensive Assessment of Soil Health (CASH) soil respiration method was used to quantify soil respiration. Averaged over all sites, $\mathrm{N}$ fertilization did not impact soil respiration, but at four sites soil respiration decreased as $\mathrm{N}$ fertilizer rate applied at-planting increased. Across all siteyears, soil respiration was moderately related to the economical optimum $\mathrm{N}$ rate (EONR) $\left(r^{2}=0.21\right)$. However, when analyzed by year, soil respiration was more strongly related to EONR in $2016\left(\mathrm{r}^{2}=0.50\right)$ and poorly related for the first two years $\left(\mathrm{r}^{2}<0.20\right)$. These results illustrate the factors influencing the ability of laboratory soil respiration to estimate corn $\mathrm{N}$ response, including growing-season weather, and the potential of fusing soil respiration with other soil and weather measurements for improved $\mathrm{N}$ fertilizer recommendations.
\end{abstract}

\section{1 | INTRODUCTION}

Abbreviations: CASH, comprehensive assessment of soil health; EONR, economical optimal $\mathrm{N}$ rate; $\mathrm{KOH}$, potassium hydroxide.

Historically, $\mathrm{N}$ soil fertility research has focused on determining the amount of supplemental $\mathrm{N}$ needed to 
optimize yield (Jokela \& Randall, 1989; Russell, 1963; Shapiro \& Wortman, 2006; Stecker, Buchholz, Hanson, Wollenhaupt, \& McVay, 1995; Triplett, Haghiri, \& van Doren, 1979). At present, with increasing financial and environmental pressures, the greater focus has been to provide recommendations that align with the $\mathrm{N}$ rate at which profitability is maximized, also known as the economic optimum N rate (EONR; Scharf et al., 2005; Vanotti \& Bundy, 1994; Williams et al., 2007; Franzluebbers, 2018a). However, spatial and temporal variability in crop $\mathrm{N}$ requirements between growing seasons, both within and among fields, makes estimating EONR difficult. Various tools for predicting crop $\mathrm{N}$ fertilizer needs that utilize tests to approximate $\mathrm{N}$ mineralization have been explored. Examples include the anaerobic potentially mineralizable N test (Stanford \& Smith, 1972), Illinois Soil N test (Khan, Mulvaney, \& Hoeft, 2001; Morris et al., 2018; Williams et al., 2007), soil microbial biomass (chloroform fumigation; Brookes, Landman, Pruden, \& Jenkinson, 1985), and $\mathrm{NH}_{4}$-N by oxidative release (Stanford \& Smith, 1978). Varying success has been documented using these approaches (Gagnon, Lalande, \& Fahmy, 2001; Griffin, 2008; Morris et al., 2018; Williams et al., 2007).

Additional tests estimate $\mathrm{N}$ requirements by measuring soil organic $\mathrm{C}$ fractions. Soil organic $\mathrm{C}$ can be divided into labile and recalcitrant portions, with the latter being relatively stable in soils (Singh, Schoonover, Williard, Kaur, \& Crim, 2018; Weil, Islam, Stine, Gruver, \& Samson-Liebig, 2003). Labile substances are thought to be water soluble and quickly decomposed by the soil microbial community (Ghani, Dexter, \& Perrott, 2003; Singh et al., 2018). These substances are composed of plant amino acids, microbial enzymes, and other plant residues which are decomposed easily by soil microorganisms with the mineral constituents made available for plant uptake and growth (Lehmann \& Kleber, 2015; Soil Science Society of America, 1997; Weil \& Brady, 2015). Some studies have found labile $\mathrm{C}$ measurements are sensitive to changes in management practices (e.g., tillage, cover crops, rotation), environmental variations (e.g., soil texture, landscape), and soil productivity (e.g., above ground biomass) (Culman et al., 2012; Hurisso et al., 2016; Weil et al., 2003). Therefore, measuring labile $\mathrm{C}$ fractions that reflect microbial activity and soil health status could potentially aid in crop $\mathrm{N}$ management decisions.

Under controlled conditions and without the addition of new $\mathrm{C}$ inputs (e.g., substrates), laboratory methods empirically and operationally separate labile $\mathrm{C}$ from stabilized $\mathrm{C}$ through a variety of approaches. One common biological approach is through mineralization of organic $\mathrm{C}$ by soil microbes (Mclauchlan \& Hobbie, 2004). Microbes are presumed to mineralize labile $\mathrm{C}$ fractions first followed by more stable fractions. Microbial activity can be mea-

\section{Core Ideas}

- Soil respiration should not be used alone to estimate corn $\mathrm{N}$ need.

- At 4 of 49 sites, soil respiration responded to added inorganic $\mathrm{N}$ fertilizer.

- Storage and method type do not alter the trend of soil respiration.

sured by quantifying the $\mathrm{CO}_{2}$ produced during a set incubation period (Alvarez \& Alvarez, 2000; Pastor, Dewey, Naiman, McInnes, \& Cohen, 1993). This approach is often referred to as $\mathrm{C}$ mineralization or soil respiration and is commonly used as a soil health indicator (Moebius-Clune et al., 2016; Wade, Culman, Hurisso, \& Horwath, 2018). Furthermore, these tests have been related to soil microbial biomass $\mathrm{C}, \mathrm{N}$ mineralization (Franzluebbers, Pershing, Crozier, Osmond, \& Schroeder-Morerno, 2018), and other soil properties, and have been shown to be sensitive to various management practices (Franzluebbers, 1999; Hurisso et al., 2016). Therefore, measuring and understanding soil respiration as a metric of soil microbial activity and its influence on soil nutrient availability could ultimately assist with optimizing $\mathrm{N}$ fertilizer management. However, $\mathrm{N}$ fertilization has been shown to have contradictory effects on soil respiration and other microbial measurements. Studies have observed that added $\mathrm{N}$ fertilizer increased soil respiration through stimulation of soil microbes (Bowden, Davidson, Savage, Arabia, \& Steudler, 2004; Burton, Pregitzer, Reuss, Hendrick, \& Allen, 2002; Liljeroth, Van Veen, \& Miller, 1990; Pregitzer et al., 2000). However, other studies have found that as $\mathrm{N}$ fertilizer rates increased, soil organic matter decomposition and respiration slowed, ultimately increasing total soil organic matter (Aber et al., 1993; Cao \& Woodward, 1998). In addition, a study comparing the effect of inorganic $\mathrm{N}$ fertilization on soil microbial biomass found contrasting results between grassland and annual cropping systems. Specifically, added $\mathrm{N}$ decreased soil microbial biomass by $12 \%$ in the grassland system while increased soil microbial biomass by $13.6 \%$ in annual cropping systems (Geisseler, Lazicki, \& Scow, 2016). Thus, given these findings, the relationship between soil respiration and added $\mathrm{N}$ fertilizer, available soil $\mathrm{N}$, and crop $\mathrm{N}$ need are not well understood and require further study.

One soil health package that includes a soil respiration component, and has received a lot of recent attention, is the Haney Test, also referred to as the Soil Health Nutrient Tool. It incorporates a 24-h $\mathrm{CO}_{2}$ "flush" or "burst" test (i.e., Solvita $\mathrm{CO}_{2}$-Burst), water extraction of $\mathrm{N}$ and 
organic $\mathrm{C}$, and the weak acid extraction of inorganic $\mathrm{N}$ (Doran, Kettler, \& Tsivou, 1997; Franzluebbers, 2016; Franzluebbers, Haney, Honeycutt, Schomberg, \& Hons, 2000; Haney et al., 2010; Haney, Haney, Hossner, \& Arnold, 2006; Yost et al., 2018). Using these measurements, a soil health number and plant-available $\mathrm{N}$ calculations have been proposed and used to calculate $\mathrm{N}$ fertilizer rates for $\mathrm{N}$-demanding crops including corn. When compared to traditional grower $\mathrm{N}$ fertilizer rates in Texas, the Haney Test was found to recommend less $\mathrm{N}$ while maintaining profit (Harmel \& Haney, 2013). However, when compared to EONR in corn across 17 U.S. Midwest Corn Belt sites, the Haney Test $\mathrm{N}$ recommendation did not perform as well ( $r^{2}=0.24$; Yost et al., 2018). Interestingly in this same evaluation, the 24-h Solvita $\mathrm{CO}_{2}$-Burst test portion of the Haney test related relatively well to EONR $\left(r^{2}=0.61\right)$. In another study with 47 corn $\mathrm{N}$ response trials across North Carolina and Virginia, measured soil respiration also related well to EONR $\left(r^{2}=0.45\right.$; Franzluebbers, 2018). On a long-term field trial in Michigan, soil respiration outperformed the Pre-Sidedress Nitrate Test (PSNT) and leaf chlorophyll content methods for estimating earlyseason corn N status (Culman, Snapp, Green, \& Gentry, 2013). These results demonstrate the potential opportunity for using soil respiration to estimate in-season $\mathrm{N}$ fertilizer rate recommendations. Since $\mathrm{N}$ fertilizer is imperative to corn production, the relationship between $\mathrm{N}$ fertilizer and soil respiration warrants further evaluation. The Yost et al. (2018) study was only performed on the third year of a three-year investigation. The meaningful relationship found between respiration and EONR from 17 sites in that one year, prompted a more thorough exploration across the complete three-year dataset. Thus, the objective of this research was to evaluate over multiple growing seasons and diverse soil environments the relationship of soil respiration to corn yield response to in-season $\mathrm{N}$ fertilization (i.e. EONR). A secondary objective was to determine if the amount of $\mathrm{N}$ applied at planting significantly changed soil respiration.

\section{MATERIALS AND METHODS}

\section{1 | Research sites, treatments, and the economical optimal $\mathrm{N}$ rate}

This research was conducted as part of a public-private collaboration between eight land-grant universities (Iowa State University, University of Illinois, Purdue University, University of Minnesota, University of Missouri, North Dakota State University, University of Nebraska, and the University of Wisconsin) within the U.S. Corn Belt and DuPont Pioneer (Kitchen et al., 2017).

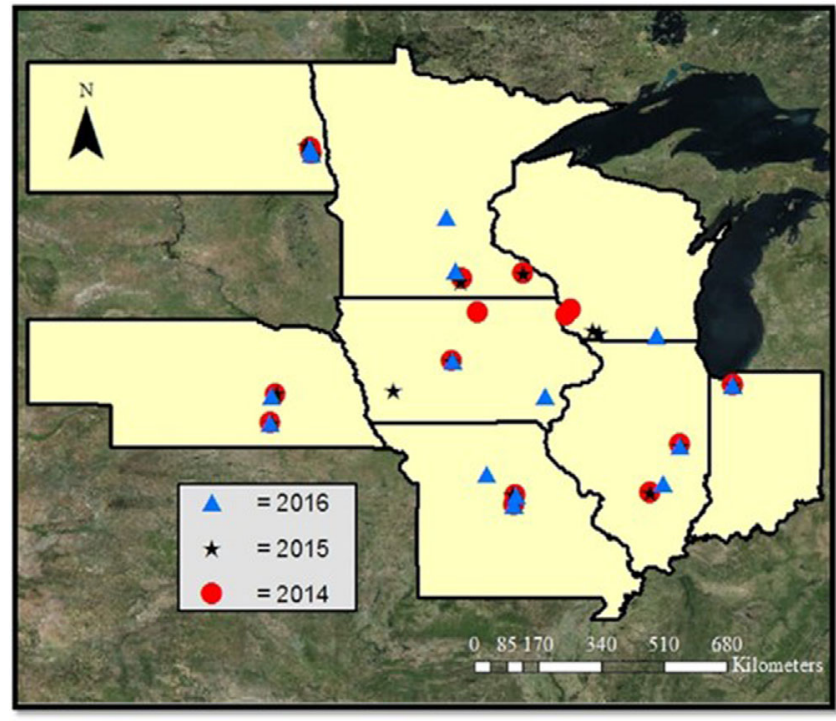

F I G URE 1 Field research sites were located within eight U.S. Midwest Corn Belt states (Iowa, Illinois, Indiana, Minnesota, Missouri, Nebraska, North Dakota, and Wisconsin). Each state contained two sites for each of the three growing seasons (2014-2016; Missouri had three sites for the 2016 growing season), totaling 49 sites

Forty-nine corn N-response trials were conducted during 2014 to 2016 in eight Midwestern Corn Belt States. In each state, two sites ranging in productivity (i.e. one site located on highly productive soil and the other on relatively less productive soil) were selected for each growing season, equaling six sites per state (Missouri had three in 2016; Figure 1).

Historical yield combined with the judgement and experience of each state's principal investigator was used to determine relative and contrasting site productivity (i.e. within a state, two sites were chosen with one site historically out-yielding the other). Further soil and site characteristics are reported in Kitchen et al. (2017). Research sites were planted at a target population of 86,450 plants ha ${ }^{-1}$ using Pioneer hybrids (DuPont Pioneer, Johnstown, IA) found suitable on a regional level for the selected sites. Most research sites were corn following soybean, however five sites followed corn. There were five tile drained sites and eight irrigated sites. All but 14 sites received at least some form of tillage. Planting dates ranged from April 6 to May 23. Descriptions of management for all sites are presented in Table 1.

Plot dimensions were state and site dependent and were determined by the planting (planter width) and harvesting (combine width) equipment available. While plot dimensions ranged from 12.2 to $18.2 \mathrm{~m}$ in length and 3.05 to $9.1 \mathrm{~m}$ wide, the minimal plot harvest area was $18.6 \mathrm{~m}^{2}$. Average size per site was 0.4 ha. Of the 16 different $\mathrm{N}$ application rates used for the broader project, only nine (Table 2) were used for this analysis with each being replicated four 
TA B L E 1 Management description for the 49 sites for the 2014-2016 growing seasons. Each of the eight participating states chose two contrasting locations with varying productivity

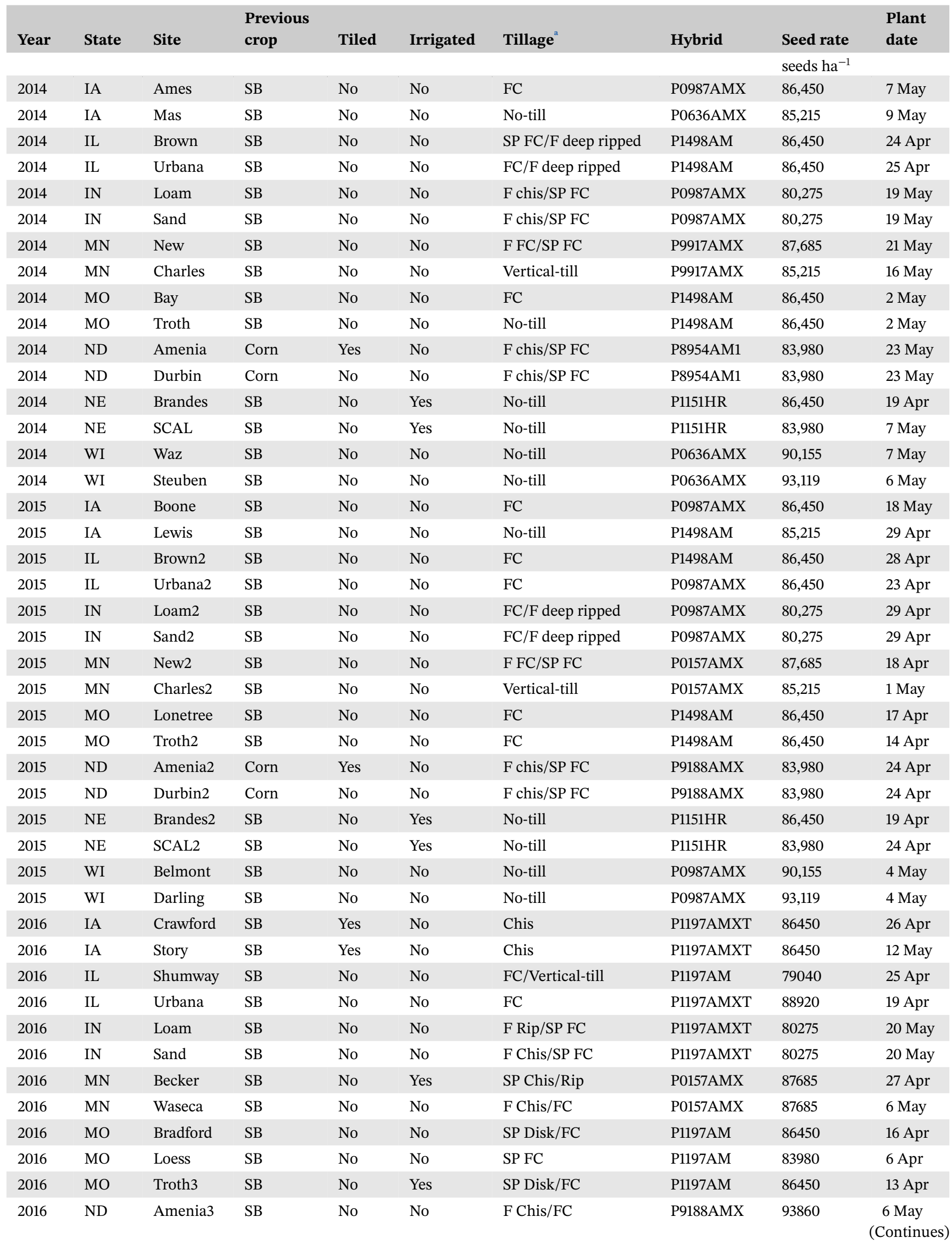


TABLE 1 (Continued)

\begin{tabular}{llllllllll} 
Year & State & Site & $\begin{array}{l}\text { Previous } \\
\text { crop }\end{array}$ & Tiled & Irrigated & Tillage & Plant \\
2016 & ND & Durbin3 & SB & Yes & No & F Chis/FC & P9188AMX & S8920 & 6 May \\
\hline 2016 & NE & Kyes & SB & No & Yes & No-till & P1197AMT & 79040 & 5 May \\
\hline 2016 & NE & SCAL3 & Corn & No & Yes & No-till & P1197AMT & 83980 & 12 May \\
2016 & WI & Lorenzo & SB & No & No & No-till & P0157AMX & 86450 & 23 Apr \\
2016 & WI & Plano & SB & No & No & No-till & P0157AMX & 86450 & 23 Apr \\
\hline
\end{tabular}

${ }^{a}$ FC, field cultivated; F, fall; Chis, Chisel; SP, spring.

TA B L E 2 Nine different $\mathrm{N}$ fertilizer rates split over two times were replicated four times at each site. Treatments 1, 2, and 9-14 were used to calculate the economic optimum $\mathrm{N}$ fertilizer rate for each site location. Treatments 1, 2, and 6 were used for soil respiration analysis

\begin{tabular}{|llll|}
\hline Trt \# & Planting $\mathbf{N}$ & Topdress $\mathbf{~}$ & Total N \\
\hline 1 & $\mathrm{~kg} \mathrm{ha}^{-1}$ & & \\
\hline 2 & 0 & 0 & 0 \\
\hline 6 & 45 & 0 & 45 \\
\hline 9 & 225 & 0 & 225 \\
\hline 10 & 45 & 45 & 90 \\
\hline 11 & 45 & 90 & 135 \\
\hline 12 & 45 & 135 & 180 \\
\hline 13 & 45 & 180 & 225 \\
\hline 14 & 45 & 225 & 270 \\
\hline
\end{tabular}

times in a randomized complete block design (Kitchen et al., 2017). Nitrogen treatments were broadcast applied using dry-prilled $\mathrm{NH}_{4} \mathrm{NO}_{3}$ fertilizer. The "at-planting" fertilizer was applied within $48 \mathrm{~h}$ of initial planting while the sidedress fertilizer was applied between the V8 to V10 leaf stage. Treatment numbers reported here correlate with those presented in Kitchen et al. (2017). Treatment one was the non-fertilized control. Treatments 2 and 6 received all $\mathrm{N}$ at planting, while treatments 9 to 14 received $45 \mathrm{~kg} \mathrm{~N} \mathrm{ha}^{-1}$ at planting and the rest at sidedress in $45 \mathrm{~kg} \mathrm{~N} \mathrm{ha}^{-1}$ increments from 45 to $270 \mathrm{~kg} \mathrm{~N} \mathrm{ha}^{-1}$.

The EONR was determined by Kitchen et al. (2017) for each of the 49 site-years by calculating site-specific corn yield $\mathrm{N}$ response curves (i.e. correlating the individual $\mathrm{N}$ rates applied to their resulting yield). While the quadraticplateau model was used to determine most of the 49-site corn yield $\mathrm{N}$ response functions, quadratic and linearplateau models were also utilized when appropriate. This calculation was made using the treatments in Table 2, the yield data reported in Kitchen et al. (2017), and a N price/corn price ratio of $\$ 0.88 \mathrm{~kg}^{-1} \mathrm{~N}$ to $\$ 0.03 \mathrm{~kg}^{-1}$ grain. Further details are provided in Kitchen et al. (2017). However, this analysis used soil respiration to estimate $\mathrm{N}$ need from $\mathrm{V} 5$ to the end of the growing season, therefore the atplanting $\mathrm{N}$ rate of $45 \mathrm{~kg} \mathrm{~N} \mathrm{ha}^{-1}$ was subtracted from the final season-long EONR values.

\subsection{Original soil sampling and previous analysis}

The previous study by Yost et al. (2018) utilized samples from the 2016 growing season for the soil respiration assessment. Eight soil cores (32 $\mathrm{mm}$ in diameter) were collected and combined into one sample per replicate prior to planting at two depth increments $(0-5$ and 5-15 cm), and the Haney test was evaluated on a site-level basis. Following laboratory analysis, the soil samples were placed in storage at ambient air temperature.

There were no pre-plant soil samples collected by plot as part of the broader project. However, at all 49 sites from 2014-2016, three 0-30 cm V5 soil samples (25 mm diameter) were collected and composited from each at-planting $\mathrm{N}$ rate and replicate, air-dried, and analyzed for soil nitrate. After nitrate analysis, the dry soil samples were placed in storage with the Yost et al. (2018) samples previously mentioned (Kitchen et al., 2017). Ultimately, the V5 soil samples were chosen for this analysis due to the objective to improve in-season $\mathrm{N}$ fertilizer application rates. In the spring of 2018, the V5 soil samples for the 0,45 , and $225 \mathrm{~kg} \mathrm{~N} \mathrm{ha}^{-1}$ at-planting $\mathrm{N}$ fertilizer treatments were retrieved from storage along with the soil samples used by Yost et al. (2018). The soils were all subsampled and prepared for soil respiration tests for this study.

\section{3 | Cornell soil respiration test}

While Yost et al. (2018) used the 24-h Solvita $\mathrm{CO}_{2}$-Burst test to represent soil respiration, the investigation reported here followed a slightly modified method from Cornell University's Comprehensive Assessment of Soil Health (CASH) manual (Moebius-Clune et al., 2016). The CASH soil respiration method is a sealed chamber alkali trap respirometry test that measures soil biological activity 
TA B L E 3 Results of the comparison between the Solvita and Cornell Soil Health Assessment (CASH) soil respiration methods and between $\mathrm{CASH}$ and the economic optimal $\mathrm{N}$ rate (EONR) by sample storage, depth, and time

\begin{tabular}{|c|c|c|c|c|c|c|c|c|c|}
\hline $\begin{array}{l}\text { Sample } \\
\text { Set \# }\end{array}$ & $\begin{array}{l}\text { Sample } \\
\text { Year(s) }\end{array}$ & $\begin{array}{l}\text { Sample } \\
\text { Sites }\end{array}$ & $\begin{array}{l}\text { Sample } \\
\text { Time }^{\mathrm{a}}\end{array}$ & $\begin{array}{l}\text { Sample } \\
\text { Depth }\end{array}$ & $\begin{array}{l}\text { Sample } \\
\text { Storage }\end{array}$ & $\begin{array}{l}\text { Resp. } \\
\text { Method }^{\mathrm{b}}\end{array}$ & Comparison Test & $\mathbf{r}^{2}$ & slope \\
\hline & & & & $-\mathrm{m}$ & months & & & & \\
\hline 2 & 2016 & 9 & Preplant & $0-15$ & $\sim 24$ & $\mathrm{CASH}$ & Compared to sample set \#1 & 0.76 & 0.35 \\
\hline 3 & 2016 & 9 & Preplant & $0-30$ & $\sim 24$ & $\mathrm{CASH}$ & Compared to sample set $\# 2$ & 0.98 & 0.65 \\
\hline 5 & $2014-16$ & 49 & V5 & $0-30$ & $24-36$ & CASH & $\begin{array}{l}\text { Compared to EONR value } \\
\text { for each respective site }\end{array}$ & 0.21 & -0.34 \\
\hline
\end{tabular}

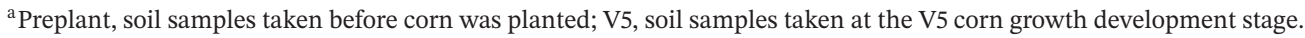

${ }^{\mathrm{b}}$ Solvita, 24-h $\mathrm{CO}_{2}$-Burst; CASH, Cornell Soil Health Assessment soil respiration test.

through the output of $\mathrm{CO}_{2}$ during a 4-day incubation period (Zibilske, 1994). The analysis was performed in the USDA-ARS Soil Quality Lab on the University of Missouri campus. In short, soil samples were air dried and sieved to $2 \mathrm{~mm}$ (originally sieved to $2 \mathrm{~mm}$ for nitrate tests prior to storage; CASH protocol is $8 \mathrm{~mm}$ ), then a $20 \mathrm{~g}$ subsample of soil was placed in an aluminum tray at the bottom of a Mason jar. $\mathrm{A} \mathrm{CO}_{2}$ trap assembly containing $9 \mathrm{ml}$ of $0.5 \mathrm{M}$ potassium hydroxide $(\mathrm{KOH})$ was added to the jar, and $7.5 \mathrm{ml}$ of deionized water was added to the bottom of the Mason jar below the aluminum tray to facilitate capillary rewetting of the soil sample through holes in the tray. The samples were then incubated for 4-days at $20^{\circ} \mathrm{C}$ along with a reference soil and a blank. Following incubation, an electrical conductivity (EC) probe was used to measure and record the $\mathrm{EC}$ of the $\mathrm{KOH}$ trap for each sample, then standard conversions were used to calculate $\mathrm{mg} \mathrm{CO}_{2}-\mathrm{C} \mathrm{kg}^{-1}$ soil. Further protocol details can be found in the Cornell Soil Health Assessment training manual (Moebius-Clune et al., 2016).

This study varied from the Yost et al. (2018)) study with respect to soil sample timing, sample depth, and respiration method. Therefore, a series of tests were performed on a subset of sites ( 9 of the original 17 sites) to determine how the Haney and CASH respiration methods compared. The two methods were highly correlated with each other $\left(\mathrm{r}^{2}\right.$ ranged from 0.76-0.98) and detailed results from the comparison are summarized in Table 3.

\section{4 | Statistical analyses}

All data were analyzed using SAS 9.2 (SAS Institute Inc., Cary, NC) with $\alpha=.05$. A within-site analysis was performed to determine the effect of $\mathrm{N}$ fertilizer rate on soil respiration using PROC GLM MANOVA. This function allows for a multivariate analysis of variance with miss- ing dependent variables. This was necessary since some sites had missing soil respiration values. Also, a similar analysis was performed across all 49 sites to determine within-state or regional differences between $\mathrm{N}$ fertilizer rate and soil respiration. Linear and quadratic regressions relating EONR to soil respiration (averaged across replications) were developed using the REG procedure of SAS.

\section{3 | RESULTS AND DISCUSSION}

\section{1 $\quad$ Storage and respiration method comparison}

Before the respiration results of this study could be used to address the objectives of relating soil respiration to atplanting $\mathrm{N}$ rates and EONR, several additional comparisons were conducted as summarized in Table 3. Results from nine 2016 sites using the Solvita $\mathrm{CO}_{2}$-Burst method [as reported by Yost et al. (2018)] were first compared to results from the CASH method and found highly correlated (Figure 2; $\mathrm{r}^{2}=0.76$ ). Overall, soil respiration results were about three times greater using the $\mathrm{CASH}$ soil respiration test than the Solvita $\mathrm{CO}_{2}$-Burst (slope $=0.35$ ), a difference that could be attributed to the incubation length (Franzluebbers \& Haney, 2018a). The Solvita $\mathrm{CO}_{2}$-Burst test has an incubation length of $24 \mathrm{~h}$ while the CASH soil respiration test uses a 4-day incubation. Naturally, the longer incubation time allows for more $\mathrm{CO}_{2}$ to be respired.

Since the respiration tests were not run simultaneously but were performed at two different time points 2 years apart, the effect of soil sample storage cannot be accounted for. However, accounting for the incubation duration, the soil respiration rates were approximately the same. From this, it can be presumed that sample storage for two years had a minor effect on soil respiration (Meyer, Welp, \& Amelung, 2019). Further, the relative differences among 


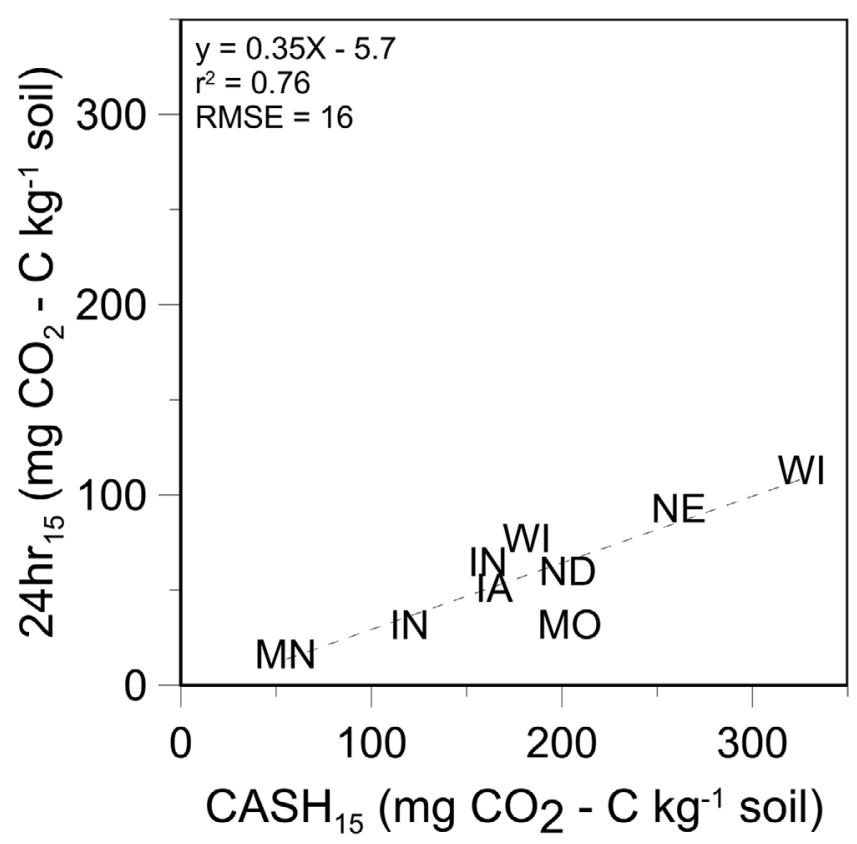

F I G URE 2 Relating soil respiration measurements in the top $15 \mathrm{~cm}$ of soil from the Solvita $\mathrm{CO}_{2}$-Burst analysis $\left(24 \mathrm{hr}_{15}\right)$ to the Cornell Soil Health Assessment soil respiration analysis $\left(\mathrm{CASH}_{15}\right)$. Soil samples were analyzed using the 24-h method in the spring of 2016. Following two years of storage, soil respiration was again measured using the 4-day incubation CASH method. These two soil respiration measurements were found significantly related. These results demonstrate soils with low respiration amounts prior to storage will have low respiration amounts following storage

sites followed the same trend for both tests, finding that sites with lower respiration measurements prior to storage were still lower following storage. These results were similar to the observations made by others suggesting if soil samples are correctly processed and stored, future soil respiration tests are valid and comparable (e.g., Jones \& Shannon, 1999). Additional comparisons using the CASH method but contrasting soil sample time and soil sample depth were also significant $\left(\mathrm{r}^{2}\right.$ values reported in Table 3).

Both soil respiration tests (Solvita 24-h $\mathrm{CO}_{2}$-Burst and $\mathrm{CASH}$ ) follow a protocol of rewetting air-dried soil via capillary forces to propagate suitable conditions for microbial activity and the release of $\mathrm{CO}_{2}$. However, the means of capturing and measuring the released $\mathrm{CO}_{2}$ is different. At the time of analysis (spring 2016; Yost et al., 2018), the Solvita 24-h $\mathrm{CO}_{2}$-Burst lab test protocol used Solvitaspecific detector probes (referred to as paddles). Prior to the start of the 24-h incubation, a $\mathrm{CO}_{2}$ colorimetric detector probe was inserted into the test jar. Following incubation, the probe was removed and inserted into a Solvita Digital Color Reader. The digital colorimetric value was then converted to milligrams per kilogram of $\mathrm{CO}_{2}-\mathrm{C}$. This approach is relatively expensive for quantifying soil respiration and dependent on the specific detector probe used. Furthermore, detector probes can become saturated for soils with high soil respiration, resulting in an underestimation of results (McGowen, Sharma, Deng, Zhang, \& Warren, 2018; Woods End Laboratories, 2016). The cost per analysis of the CASH soil respiration test is less since it does not rely on detector probes or a Digital Color Reader. While the CASH incubation time is longer (which leads to increased space and time requirements), analytical sensitivity and range appears to be greater. This is similar to what others have reported (Franzluebbers \& Haney, 2018). Overall, the findings of this research suggest the CASH soil respiration test is equally informative and potentially more easily adopted by service laboratories for producers. Further discussion regarding soil respiration methodologies can be found in Franzluebbers (2018b).

\section{2 | Soil respiration and $\mathbf{n}$ fertilizer rate}

Across all years and sites there were no significant differences in CASH soil respiration measurements among the at-planting 0,45 , and $200 \mathrm{~kg} \mathrm{~N} \mathrm{ha}^{-1} \mathrm{~N}$ fertilizer rates (Table 4). However, when analyzed by site, soil respiration among the three $\mathrm{N}$ fertilizer rates was found to be significantly different for five sites (Figure 3). Soil respiration for four of the five sites decreased with $\mathrm{N}$ fertilization. While added $\mathrm{N}$ fertilizer increases the labile pool of $\mathrm{N}$, changes in soil $\mathrm{pH}$ and other soil and plant growth factors are likely altering the soil microbial environment (Jones \& Shannon, 1999). While no definitive causal mechanism can be provided to explain why these sites experienced a decrease in soil respiration with added $\mathrm{N}$, soil $\mathrm{pH}$ is one plausible cause. The $\mathrm{pH}$ values for these four sites were all <6.4. However, other sites with no significant differences between soil respiration and $\mathrm{N}$ fertilizer rates also had soil $\mathrm{pH}$ values $<6.4$ (data no included). Potentially, soil acidity from nitrification of ammonium-nitrate fertilizer (Sylvia et al., 2005) inhibited microbial activity and soil respiration. Another possible cause for decreased soil respiration may be the effect added $\mathrm{N}$ had on $\mathrm{C}$ storage and enzyme activity. Lignin-modifying enzymes, responsible for assisting in substrate breakdown, have been found to be suppressed with the addition of $\mathrm{N}$ (Chen et al., 2018). This may result in increased $\mathrm{C}$ storage and a possible decline in soil respiration.

The remaining site impacted by $\mathrm{N}$ fertilization had the opposite relationship; soil respiration increased with fertilization. The $\mathrm{pH}$ at this site was 7.9 and highly buffered with free calcium carbonate. Yet this site had the highest total $\mathrm{C}$ (twice as much as the next highest site) and the lowest potentially mineralizable $\mathrm{N}$ (data not shown), suggesting the microbial community was $\mathrm{N}$ limited. This site in North 
TA B L E 4 Soil respiration generated by the Comprehensive Assessment of Soil Health (CASH) method at the V5 corn growth development stage for three different at-planting $\mathrm{N}$ fertilizer rates $\left(0,45\right.$, and $\left.200 \mathrm{~kg} \mathrm{~N} \mathrm{ha}^{-1}\right)$ at all 49 site locations. Following an ANOVA test, there was no significant difference in soil respiration between $\mathrm{N}$ fertilizer rates at the regional level $(\alpha=.05)$. However, when analyzed within site, there were five locations where soil respiration was found significantly different between $\mathrm{N}$ fertilizer rates $(\alpha=.05)$ and are marked in the $\mathrm{N}$ Rate Sig. column below. Also, because soil respiration was used to estimate $\mathrm{N}$ need from V5 to the end of the growing season, the economical optimal $\mathrm{N}$ fertilizer rates (EONR) presented here have been adjusted by subtracting the at-planting $\mathrm{N}$ fertilizer amount $\left(45 \mathrm{~kg} \mathrm{~N} \mathrm{ha}^{-1}\right)$. Ultimately, representing the amount of $\mathrm{N}$ that would be economical as a sidedress

\begin{tabular}{|c|c|c|c|c|c|c|c|}
\hline Year & State & Site & EONR & O N Resp. & 45 N Resp. & $\begin{array}{l}200 \mathrm{~N} \\
\text { Resp. }\end{array}$ & $\begin{array}{l}\text { N Rate } \\
\text { sig. }\end{array}$ \\
\hline & & & $\mathrm{kg} \mathrm{N} \mathrm{ha}^{-1}$ & $\begin{array}{c}\mathrm{mg} \mathrm{CO}-\mathrm{C} \\
\mathrm{kg}^{-1} \text { soil }\end{array}$ & & & \\
\hline 2014 & IA & Ames & 109 & . & 178 & 185 & \\
\hline 2014 & IA & Mas & 107 & 229 & 220 & 193 & \\
\hline 2014 & IL & Brown & 190 & 158 & 140 & 109 & \\
\hline 2014 & IL & Urbana & 216 & 228 & 213 & 182 & $*$ \\
\hline 2014 & IN & Loam & 125 & 130 & 118 & 118 & \\
\hline 2014 & IN & Sand & 145 & 105 & 95 & 86 & \\
\hline 2014 & $\mathrm{MN}$ & New & 112 & 277 & 238 & 238 & \\
\hline 2014 & $\mathrm{MN}$ & Charles & 72 & . & 122 & 151 & \\
\hline 2014 & MO & Bay & 131 & 200 & 196 & 195 & \\
\hline 2014 & MO & Troth & 141 & 168 & 185 & 173 & \\
\hline 2014 & $\mathrm{ND}$ & Amenia & 118 & . & 249 & 228 & \\
\hline 2014 & ND & Durbin & 119 & . & 238 & 255 & \\
\hline 2014 & $\mathrm{NE}$ & Brandes & 200 & 116 & 134 & 136 & \\
\hline 2014 & $\mathrm{NE}$ & SCAL & 92 & 187 & 210 & 173 & \\
\hline 2014 & WI & Steuben & 32 & 296 & 286 & 243 & \\
\hline 2014 & WI & Waz & 73 & 225 & 196 & 213 & \\
\hline 2015 & IA & Boone & 141 & 167 & 126 & 143 & * \\
\hline 2015 & IA & Lewis & 61 & 182 & 146 & 140 & $*$ \\
\hline 2015 & IL & Brown2 & 78 & 154 & 117 & 115 & \\
\hline 2015 & IL & Urbana2 & 191 & 205 & 185 & 166 & \\
\hline 2015 & IN & Loam2 & 114 & 156 & 149 & 137 & \\
\hline 2015 & IN & Sand2 & 160 & 119 & 129 & 84 & \\
\hline 2015 & $\mathrm{MN}$ & New2 & 105 & 227 & 210 & 203 & \\
\hline 2015 & $\mathrm{MN}$ & Charles2 & 120 & 165 & 165 & 179 & \\
\hline 2015 & MO & Lonetree & 266 & 162 & 156 & 158 & \\
\hline 2015 & MO & Troth2 & 266 & 178 & 167 & 183 & \\
\hline 2015 & ND & Amenia2 & 109 & 137 & 125 & 168 & * \\
\hline 2015 & ND & Durbin2 & 93 & 239 & 224 & 227 & \\
\hline 2015 & $\mathrm{NE}$ & Brandes2 & 205 & 115 & 106 & 103 & \\
\hline 2015 & $\mathrm{NE}$ & SCAL2 & 0 & 244 & 229 & 214 & \\
\hline 2015 & WI & Belmont & 0 & 209 & 178 & 179 & \\
\hline 2015 & WI & Darling & 128 & 267 & 251 & 244 & \\
\hline 2016 & IA & Crawford & 143 & 200 & 203 & 198 & \\
\hline 2016 & IA & Story & 142 & 209 & 187 & 191 & \\
\hline 2016 & IL & Shumway & 118 & 173 & 158 & 146 & $*$ \\
\hline 2016 & IL & Urbana & 131 & 179 & 177 & 174 & \\
\hline 2016 & IN & Loam & 105 & 167 & 173 & 168 & \\
\hline 2016 & 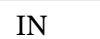 & Sand & & 122 & & & \\
\hline
\end{tabular}


TA B L E 4 (Continued)

\begin{tabular}{|c|c|c|c|c|c|c|c|}
\hline Year & State & Site & EONR & o N Resp. & 45 N Resp. & $\begin{array}{l}200 \text { N } \\
\text { Resp. }\end{array}$ & $\begin{array}{l}\text { N Rate } \\
\text { sig. }\end{array}$ \\
\hline 2016 & $\mathrm{MN}$ & Becker & 265 & 92 & . & . & \\
\hline 2016 & $\mathrm{MN}$ & Waseca & 121 & 172 & 187 & 172 & \\
\hline 2016 & MO & Bradford & 145 & 115 & 119 & 110 & \\
\hline 2016 & MO & Loess & 158 & 149 & 152 & 139 & \\
\hline 2016 & MO & Troth3 & 161 & 185 & 180 & 196 & \\
\hline 2016 & ND & Amenia3 & 0 & 196 & 217 & 195 & \\
\hline 2016 & ND & Durbin3 & 0 & . & 246 & 236 & \\
\hline 2016 & $\mathrm{NE}$ & Kyes & 133 & 208 & 190 & 189 & \\
\hline 2016 & $\mathrm{NE}$ & SCAL3 & 14 & 162 & 147 & 144 & \\
\hline 2016 & WI & Lorenzo & 33 & 241 & 286 & 336 & \\
\hline 2016 & WI & Plano & 98 & 172 & 161 & 159 & \\
\hline
\end{tabular}

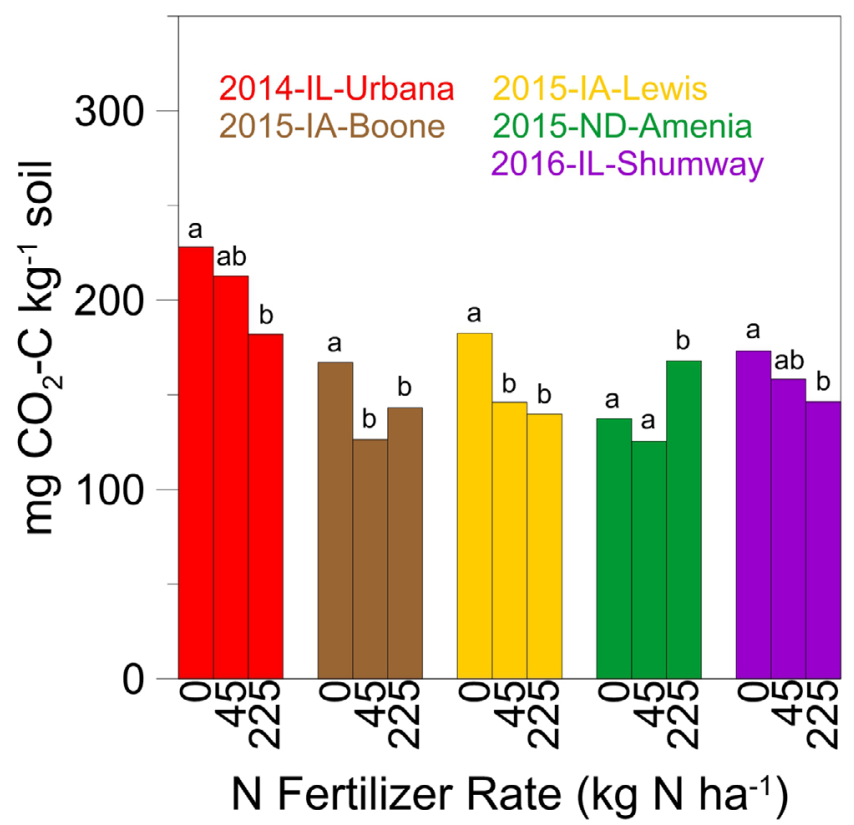

F I G URE 3 The statistical relationship comparing within-site at-planting $\mathrm{N}$ fertilizer rate and $\mathrm{V} 5$ soil respiration (measured in mg $\mathrm{CO}_{2}-\mathrm{C} \mathrm{kg}^{-1}$ soil). Following a PROC GLM MANOVA analysis (SAS 9.2), soil respiration at five of the 49 site locations were found to be significantly different between at-planting $\mathrm{N}$ application rates. Significant within-site respiration rate differences are identified by letters (e.g. for 2015-IA-Boone, the $0 \mathrm{~kg} \mathrm{ha}^{-1} \mathrm{~N}$ rate has a "a" label while the 45 and $200 \mathrm{~kg} \mathrm{~N}^{-1}$ rates have a "b" label indicating the 0 rate is different than the 45 and 200 rates). Four of the five sites experienced decreasing soil respiration with increasing $\mathrm{N}$ fertilizer amount while one site experienced the opposite, increased soil respiration with the highest applied fertilizer amount

Dakota, located within the Red River Valley, is dominated by soils known for stable $\mathrm{C}$ storage. Therefore, as more inorganic $\mathrm{N}$ fertilizer was added, soil respiration was enhanced. Importantly, soil respiration at approximately

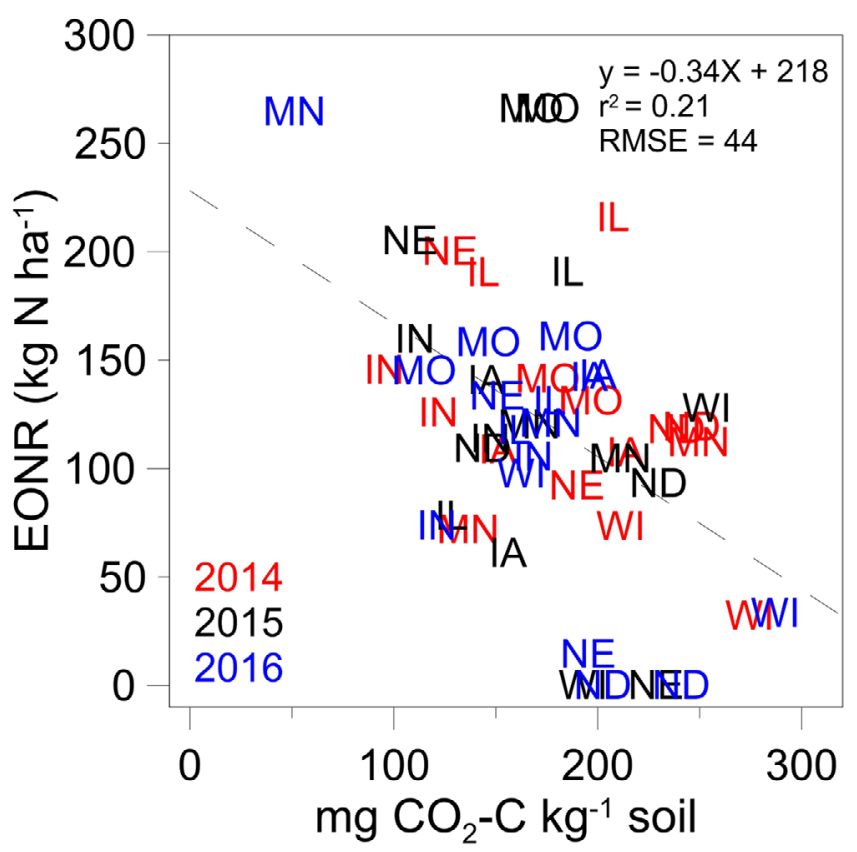

F I G U R E 4 The Cornell Soil Health Assessment soil respiration test (measured in $\mathrm{mg} \mathrm{CO}_{2}-\mathrm{C} \mathrm{kg}^{-1}$ soil) compared across three growing seasons and eight states $(\mathrm{N}=49)$ to corn economical optimal $\mathrm{N}$ rate (EONR). A significant negative relationship was found between these two variables. Results suggest that as soil respiration increased, more soil $\mathrm{N}$ was made available for plant uptake decreasing the overall amount of fertilizer $\mathrm{N}$ needed to achieve EONR

$90 \%$ of the sites in this study were not impacted by $\mathrm{N}$ fertilization. Other studies have found mixed results where inorganic $\mathrm{N}$ fertilizer amendments either enhanced (Bowden et al., 2004; Burton et al., 2002; Pregitzer et al., 2000) or suppressed (Al-Kaisi, Kruse, \& Sawyer, 2008; Bowden et al., 2004; Burton et al., 2002; Foereid, de Neergaard, \& Hogh-Jensen, 2004; Mahal et al., 2019; Ramirez, Craine, \& Fierer, 2010) respiration. Others have reported added N 

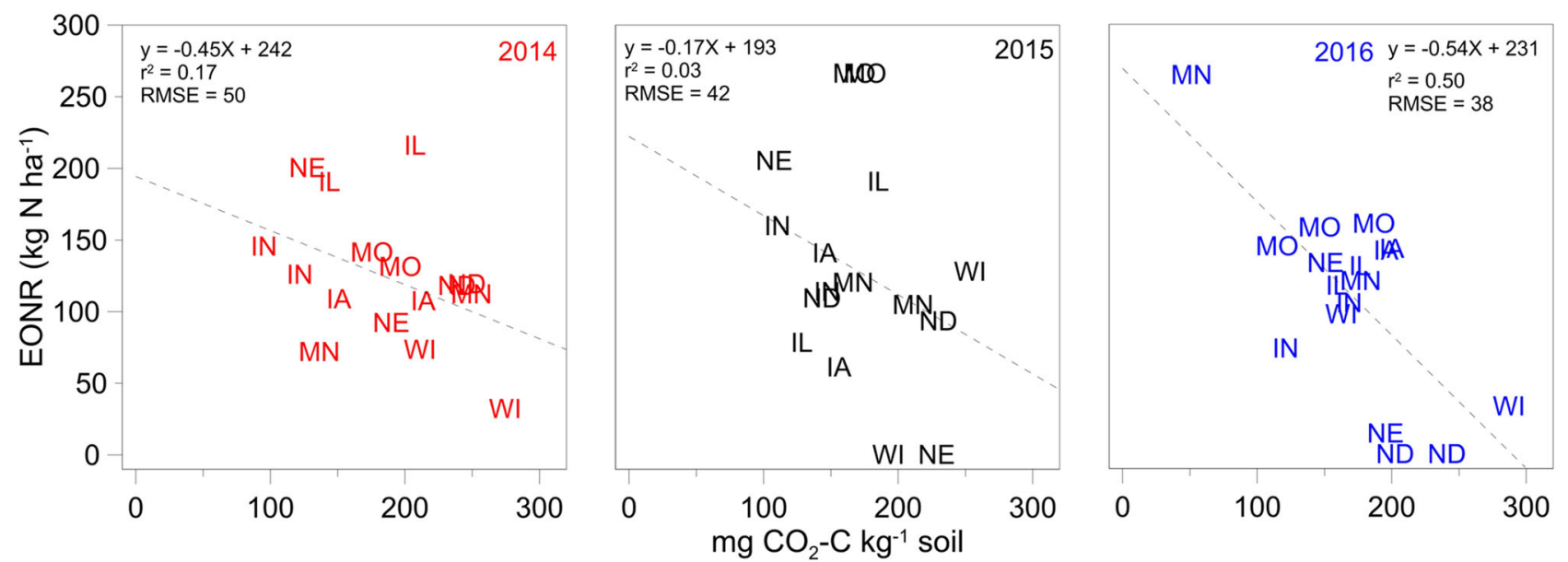

F I G U R E 5 The Cornell Soil Health Assessment soil respiration test (measured in $\mathrm{mg} \mathrm{CO}_{2}-\mathrm{C} \mathrm{kg}^{-1}$ soil) compared to the economical optimal $\mathrm{N}$ rate (EONR) in corn, separated by growing season (2014-2016). Soil respiration from the 2016 growing season was found most related to EONR

fertilizer has no effect on C mineralization (Kowalenko, Ivarson, \& Cameron, 1978; Rochette \& Gregorich, 1998; Shields, Paul, \& Lowe, 1974). Furthermore, some have found that the form of $\mathrm{N}$ applied (i.e. $\mathrm{NO}_{3}{ }^{-}$or $\mathrm{NH}_{4}{ }^{+}$) may impact soil respiration response to added $\mathrm{N}$ (Luo et al., 2016). These diverse findings can be attributed to several factors including the type and amount of the $\mathrm{N}$ fertilizer applied, environmental conditions (including temperature and precipitation regimes), soil characteristics (how much $\mathrm{N}$ is already available for microbial use), previous crop and soil management, timing of soil sample collection, and the type of vegetation grown (Beyer, 1994; Franzluebbers et al., 2000; Meier, Fyles, Mackenzie, \& Ohalloran, 1993). As observed with this analysis, the relationship between soil respiration and the added inorganic $\mathrm{N}$ fertilizer was variable and warrants further investigation into the underlying explanatory factors.

Due to the general lack of statistically significant relationships between soil respiration and at-planting $\mathrm{N}$ fertilizer amount across all sites, CASH soil respiration for each site was computed as an average across $\mathrm{N}$ rates for the remaining statistical analyses.

\section{3 | Soil respiration and the economically optimal $\mathbf{N}$ fertilizer rate}

Considering all years and sites $(\mathrm{n}=49)$, EONR was weakly correlated with the CASH soil respiration measurements (Figure 4). Generally, as soil respiration increased the amount of $\mathrm{N}$ fertilizer needed to reach EONR decreased, but only about $20 \%$ of the variability in EONR could be explained using soil respiration. Soils with greater amounts of microbial activity (i.e. soil respiration) likely mineralized more $\mathrm{N}$, ultimately lowering the total inor- ganic $\mathrm{N}$ fertilizer needed to reach EONR. An analysis by year revealed soil respiration was most strongly correlated with EONR in the 2016 growing season (Figure 5). Interestingly, this was the same growing season Yost et al. (2018) used when comparing the relationship between respiration and EONR. One way of explaining this is that the 2016 growing season weather was more ideal (i.e. soil temperature and moisture conditions were more suitable for microbial activity) and was better represented by the microbial activity observed in the CASH respiration analysis. Interestingly, only in the 2016 growing season were season-long weather metrics (i.e. total precipitation, the evenness of precipitation, and abundant and well-distributed rainfall [evenness of precipitation $\times$ total precipitation]; Tremblay et al., 2012) found to be significantly related $(\alpha=.05)$ to EONR (data not shown). Undoubtedly, the influence of weather on soil microbial activity throughout the growing season (e.g., temperature and moisture) of each year were unique, and so laboratory soil respiration may or may not be an accurate reflection of the field soil respiration that occurs after samples are collected. This was likely the case for sites that experienced above-average rainfall during the 2015 growing season. The added rainfall at these sites may have led to large amounts of $\mathrm{N}$ loss via leaching and denitrification, ultimately making it problematic for a V5 lab-based soil respiration measurement to estimate corn $\mathrm{N}$ need. This was evident when comparing the Missouri sites across all three growing seasons. Each of the three growing seasons included one river-bottom Entisol site (see Table 4, Troth) and one clay-dominated Alfisol site (Bradf). For the 2016 growing season there was an added loess-dominated Mollisol site (Loess). Soil respiration accurately estimated corn $\mathrm{N}$ need for all MO sites during the 2014 and 2016 growing seasons (Figure 5). However, during the 2015 growing season the clay-dominated site 
received nearly double the rainfall (data not shown) while the river-bottom site experienced prolonged periods of soil saturation due to high river levels. Using the year-specific linear regression model (as presented in Figure 5) to calculate and compare the soil respiration estimated EONR to the observed EONR shows this led to an approximate $100 \mathrm{~kg} \mathrm{~N} \mathrm{ha}^{-1}$ underestimation of $\mathrm{N}$ need at both sites. Simply, the $\mathrm{N}$ response estimated by soil respiration early in the growing season was minor compared to the $\mathrm{N}$ loss caused by mid- and later-season excessive wet weather.

\section{4 | Summary and conclusions}

The 24-h $\mathrm{CO}_{2}$-Burst and CASH soil respiration tests were significantly correlated with each other, signifying that they are comparable, and that soil sample storage likely had minor effects on soil respiration. These findings suggest that when soil samples are stored under the same conditions, relative differences in respiration among samples are preserved and that respiration comparisons using archived soils are valid.

Adding inorganic $\mathrm{N}$ fertilizer at planting had no significant effect on soil respiration across most sites, although an effect was detected at $10 \%$ of sites. However, no clear reason could be determined to explain the effect of $\mathrm{N}$ addition at these sites. These results combined with previous studies by others confirms that further research is needed to determine the role of $\mathrm{N}$ fertilizer additions on soil respiration.

The negative relationship observed between EONR and V5 soil respiration supports the principle that soils with greater respiration provide more plant available $\mathrm{N}$, ultimately reducing the need for supplemental inorganic $\mathrm{N}$ fertilizer. However, this relationship was weak when examined across years. Only data from one year of this threeyear study suggests that soil respiration would be helpful in adjusting $\mathrm{N}$ rate recommendations. These findings suggest lab measured soil respiration is an inconsistent stand-alone predictor of corn $\mathrm{N}$ need, especially over variable soil and weather environments. The authors of this research continue to explore how soil and weather information best informs soil respiration outcomes under variable spatial and temporal conditions. In turn, this knowledge may be used to help estimate corn $\mathrm{N}$ need. One way this could be accomplished is by using soil respiration or other soil health metrics to adjust current $\mathrm{N}$ decision tools. Others have shown or suggested $\mathrm{N}$ recommendation tools could be improved by using various soil and weather adjustments (e.g. active-optical reflectance sensors [Bean et al., 2018], pre-sidedress soil nitrate tests, yield-goal, and Maximum Return to Nitrogen calculators [Ransom, 2018; Ransom et al., 2019]). Similarly, existing N recommendation tools could be improved by adjustments using soil respira- tion. Another idea proposed by Bean (2019) delineates geographical areas based on inherit hydrologic properties then utilized other soil (including soil respiration) and weather information to estimate crop $\mathrm{N}$ need. For example, soil respiration may be best utilized on soils that are buffered against extreme weather events where respiration is not hindered by too much or too little soil water. Overall, this study highlights the need for further research investigating the utility of soil respiration as a producer test and demonstrates that it should not be used alone for making corn $\mathrm{N}$ rate fertilizer recommendations.

\section{ACKNOWLEDGMENTS}

Corteva Agriscience for funding.

\section{O R C I D}

G. Mac Bean (1) https://orcid.org/0000-0002-2206-3171

Kristen S. Veum (D) https://orcid.org/0000-0002-6492-913X

Fabian G. Fernandez (ㄴ) https://orcid.org/0000-0002-9539-

0050

David W. Franzen (10 https://orcid.org/0000-0003-4862-

8086

John E. Sawyer (1) https://orcid.org/0000-0003-4080-9616

Matt Yost (10 https://orcid.org/0000-0001-5012-8481

\section{REFER E N C ES}

Aber, J. D., Magill, A., Boone, R., Melillo, J. M., Steudler, P., \& Bowden, R. D. (1993). Plant and soil responses to three years of chronic nitrogen additions at the Harvard Forest, Petersham, MA. Ecological Applications, 3, 156-166.

Al-Kaisi, M. M., Kruse, M. L., \& Sawyer, J. E. (2008). Effect of nitrogen fertilizer application on growing season soil carbon dioxide emission in a corn-soybean rotation. Journal of Environmental Quality, 37, 325-332. https://doi.org/10.2134/jeq2007.0240

Alvarez, R., \& Alvarez, C. R. (2000). Soil organic matter pools and their associations with carbon mineralization kinetics. Soil Science Society America Journal, 64, 184-189.

Bean, G. M. (2019). Using USDA-NRCS hydrologic soil groups and drainage classifications to estimate $\mathrm{N}$ fertilizer recommendations. Ph.D. diss. Univ. of Missouri, Columbia.

Bean, G. M., Kitchen, N. R., Camberato, J. J., Ferguson, R. B., Fernandez, F. G., Franzen, D. W., ... Shanahan, J. S. (2018). Improving an active-optical reflectance sensor algorithm using soil and weather information. Agronomy Journal, 110, 2541-2551. https://doi.org/10. 2134/agronj2017.12.0733

Beyer, L. (1994). Effect of cultivation on physicochemical, humus chemical and biotic properties and fertility of two forest soils. Agriculture, Ecosystems and Environment, 48, 179-188.

Bowden, R. D., Davidson, E., Savage, K., Arabia, C., \& Steudler, P. (2004). Chronic nitrogen additions reduce total soil respiration and microbial respiration in temperate forest soils at the Harvard forest. Forest Ecology and Management, 196, 43-56.

Brookes, P. C., Landman, A., Pruden, G., \& Jenkinson, D. S. (1985). Chloroform fumigation and the release of soil nitrogen: A rapid direct extraction method to measure microbial 
biomass nitrogen in soil. Soil Biology and Biochemistry Journal, 17, 837-842. https://doi.org/10.1016/0038-0717(85)90144-0

Burton, A. J., Pregitzer, K. S., Reuss, R. W., Hendrick, R. L., \& Allen, M. F. (2002). Root respiration in North American forests: Effects on nitrogen concentration and temperature across biomes. Oecologia, 131, 559-568.

Cao, M., \& Woodward, F. I. (1998). Dynamic responses of terrestrial ecosystem carbon cycling to global climate change. Nature, 393, 249-252.

Chen, Z., Xu, Y., He, Y., Zhou, X., Fan, J., Yu, H., \& Ding, W. (2018). Nitrogen fertilization stimulated soil heterotrophic but not autotrophic respiration in cropland soils: A greater role of organic over inorganic fertilizer. Soil Biology and Biochemistry, 116, 253264. http://doi.org/10.1016/j.soilbio.2017.10.029

Culman, S. W., Snapp, S. S., Freeman, M. A., Schipanski, M. E., Beniston, J., Lal, R., ... Wander, M. M. (2012). Permanganate oxidizable carbon reflects a processed soil fraction that is sensitive to management. Soil Science Society of America Journal, 76, 494-504. https://doi.org/10.2136/sssaj2011.0286

Culman, S. W., Snapp, S. S., Green, J. M., \& Gentry, L. E. (2013). Short- and long-term labile soil carbon and nitrogen dynamics reflect management and predict corn agronomic performance. Agronomy Journal, 105, 493-502. https://doi.org/10.2134/ agronj2012.0382

Doran, J., Kettler, T., \& Tsivou, M. (1997). Field and laboratory Solvita soil test evaluation. Lincoln: Univ. Nebraska USDA-Agricultural Research Service.

Foereid, B., de Neergaard, A., \& Hogh-Jensen, H. (2004). Turnover of organic matter in a Miscanthus field: Effect of time in Miscanthus cultivation and inorganic nitrogen supply. Soil Biology \& Biochemistry, 36, 1075-1085.

Franzluebbers, A. J. (1999). Potential C and N mineralization and microbial biomass from intact and increasingly disturbed soil of varying texture. Soil Biology \& Biochemistry, 31, 1083-1090

Franzluebbers, A. J., Haney, R. L., Honeycutt, C. W., Schomberg, H. H., \& Hons, F. M. (2000). Flush of carbon dioxide following rewetting of dried soil relates to active organic pools. Soil Science Society of America Journal, 64, 613-623. https://doi.org/10.2136/sssj2000. 642613x

Franzluebbers, A. J. (2016). Should soil testing services measure soil biological activity? Agricultural and Environmental Letters, 1, 1-5. https://doi.org/10.2134/ael2015.11.0009

Franzluebbers, A. J., \& Haney, R. L. (2018a). Evaluation of soil processing conditions on mineralizable $\mathrm{C}$ and $\mathrm{N}$ across a textural gradient. Soil Science Society of America Journal, 82, 354-361. https://doi.org/10.2136/sssaj2017.08.0275

Franzluebbers, A. J., Pershing, M. R., Crozier, C., Osmond, D., \& Schroeder-Morerno, M. (2018b). Soil-test biological activity with the flush of $\mathrm{CO}_{2}$ : I. C and $\mathrm{N}$ characteristics of soils in corn production. Soil Science Society of America Journal, 82, 685-695. https://doi.org/10.2136/sssaj2017.12.0433

Franzluebbers, A. J. (2018a). Soil-test biological activity with the flush of $\mathrm{CO}_{2}$ : III. Corn yield responses to applied nitrogen. Soil. Science Society of America Journal, 82, 708-721. https://doi.org/10.2136/ sssaj2018.01.0029

Franzluebbers, A. J. (2018b). Short-term C mineralization (aka the flush of $\mathrm{CO} 2$ ) as an indicator of soil biological health. $\mathrm{CAB}$ Reveiws: Perspectives in Agriculture, Veterinary Science, Nutrition and Natural Resources, 13(7).
Gagnon, B., Lalande, R., \& Fahmy, S. H. (2001). Organic matter and aggregation in a degraded potato soil as affected by raw and composted pulp residue. Biology and Fertility of Soils Journal, 34, 441-447.

Geisseler, D., Lazicki, P. A., \& Scow, K. M. (2016). Mineral nitrogen input decreases microbial biomass in soils under grasslands but not annual crops. Applied Soil Ecology, 106, 1-10. https://doi.org/ 10.1016/j.apsoil.2016.04.015

Ghani, A., Dexter, M., \& Perrott, K. (2003). Hot-water extractable carbon in soils: A sensitive measurement of determining impacts of fertilization, grazing, and cultivation. Soil Biology \& Biochemistry, 35, 1231-1243. https://doi.org/10.1016/S0038-0717(03) 00186-X

Griffin, T. S. (2008). Nitrogen in agricultural systems, Agronomy Monograph 49. Madison, WI: ASA, CSSA, and SSSA.

Haney, R. L., Haney, E. B., Hossner, L. R., \& Arnold, J. G. (2006). Development of a new soil extractant for simultaneous phosphorus, ammonium, and nitrate analysis. Communications in Soil Science and Plant Analysis, 37, 1511-1523. https://doi.org/10.1080/ 00103620600709977

Haney, R. L., \& Haney, E. B. (2010). Simple and rapid laboratory method for rewetting dry soil for incubations. Communications in Soil Science Plant Analysis, 41, 1493-1501.

Harmel, R. D., \& Haney, R. L. (2013). Initial field evaluation of the agro-economic effects of determining nitrogen fertilizer rates with a recently developed soil test methodology. Open Journal of Soil Science, 3(2), 91-99.

Hurisso, T. T., Culman, S. W., Horwath, W. R., Wade, J., Cass, D., Beniston, J. W., ... Ugarte, C. M. (2016). Comparison of permanganate-oxidizable carbon and mineralizable carbon for assessment of organic matter stabilization and mineralization. Soil Science Society of America Journal, 80(5), 1352-1364. https://doi. org/10.2136/sssaj2016.04.0106

Jokela, W. E., \& Randall, G. W. (1989). Corn yield and residual soil nitrate as affected by time and rate of nitrogen application. Agronomy Journal, 81, 720-726. https://doi.org/10.2134/ agronj1989.00021962008100050004x

Jones, D. L., \& Shannon, D. (1999). Mineralization of amino acids applied to soils impact of soil sieving, storage, and inorganic nitrogen additions. Soil Science Society of America Journal, 63, 11991206. https://doi.org/10.2136/sssaj1999.6351199x

Khan, S. A., Mulvaney, R. L., \& Hoeft, R. G. (2001). A simple soil test for detecting sites that are nonresponsive to nitrogen fertilization. Soil Science Society of America Journal, 65, 1751-1760.

Kitchen, N. R., Shanahan, J. F., Ransom, C. J., Bandura, C. J., Bean, G. M., Camberato, J. J., ... Shafer, M. (2017). A public-industry partnership for enhancing corn nitrogen research and datasets: Project description, methodology, and outcomes. Agronomy Journal, 109, 2371-2389. https://doi.org/10.2134/agronj2017.04.0207

Kowalenko, C. G., Ivarson, K. C., \& Cameron, D. R. (1978). Effect of moisture content, temperature and nitrogen fertilization on carbon dioxide evolution from field soils. Soil Biology \& Biochemistry, 19, 417-423.

Lehmann, J., \& Kleber, M. (2015). The contentious nature of soil organic matter. Nature, 528, 60-68.

Liljeroth, E., Van Veen, J. A., \& Miller, H. J. (1990). Assimilate translocation to the rhizosphere of two wheat lines and subsequent utilization by rhizosphere microorganisms at two soil nitrogen concentrations. Soil Biology \& Biochemistry, 22, 1015-1021. 
Luo, Q., Gong, J., Zhai, Z., Pan, Y., Liu, M., Xu, S., .. Baoyin, T. (2016). The responses of soil respiration to nitrogen addition in temperate grassland in northern China. The Science of the Total Environment, 569-570, 1466-1477. https://doi.org/10.1016/j.scitotenv.2016. 06.237

Mahal, N. K., Osterholz, W. R., Miquez, F. E., Poffenbarger, H. J., Sawyer, J. E., Olk, D. C., ... Castellano, M. J. (2019). Nitrogen fertilizer suppresses mineralization of soil organic matter in maize agroecosystems. Frontiers in Ecology and Evolution, 7, 59. https: //doi.org/10.3389/fevo.2019.00059

Mclauchlan, K. K., \& Hobbie, S. E. (2004). Comparison of labile soil organic matter fractionation techniques. Soil Science Society of America Journal, 68, 1616-1625

McGowen, E. B., Sharma, S., Deng, S. D., Zhang, H., \& Warren, J. G. (2018). An automated laboratory method for measuring $\mathrm{CO}_{2}$ emissions from soils. Agricultural and Environmental Letters, 3, 180008. https://doi.org/10.2134/ael2018.02.0008

Meier, J. N., Fyles, J. W., Mackenzie, A. F., \& Ohalloran, I. P. (1993). Effects of lignosulfonate-fertilizer applications on soil respiration and nitrogen dynamics. Canadian Journal of Soil Science, 73, 233-242.

Meyer, N., Welp, G., \& Amelung, W. (2019). Effect of sieving and sample storage on soil respiration and its temperature sensitivity (Q1) in mineral soils from Germany. Biology and Fertility of Soils, 55, 825-832. https://doi.org/10.1007/s00374-019-01380-9

Moebius-Clune, B. N., Moebius-Clune, D. J., Gugino, B. K., Idowu, O. J., Schindelbeck, R. R., Ristow, A. J., ... Abawi, G. S. (2016). Comprehensive assessment of soil health: The Cornell framework manual (3.1 ed.). Cornell University.

Morris, T. F., Murrell, T. S., Beegle, D. B., Camberato, J. J., Ferguson, R. B., Grove, J., ... Yang, H. (2018). Strengths and limitations of nitrogen rate recommendations for corn and opportunities for improvement. Agronomy Journal, 110, 1-37. https://doi.org/10. 2134/agronj2017.02.0112

Pastor, J., Dewey, B., Naiman, R. J., McInnes, P. F., \& Cohen, Y. (1993). Moose browsing and soil fertility in the boreal forests of Isle Royale National Park. Ecology, 74, 467-480

Pregitzer, K. S., Zak, D. R., Maziasz, J., DeForest, J., Curtis, P. S., \& Lussenhop, J. (2000). Interactive effects of atmospheric $\mathrm{CO}_{2}$ and soil-N availability on fine roots of Populus tremuloides. Ecology Applications, 10, 18-33.

Ramirez, K. S., Craine, J. M., \& Fierer, N. (2010). Nitrogen fertilization inhibits soil microbial respiration regardless of the form of nitrogen applied. Journal of Soil Biology and Biochemistry, 42, 23362338. https://doi.org/10.1016/j.soilbio.2010.08.032

Ransom, C. J. (2018). Evaluating and improving corn nitrogen fertilizer recommendation tools across the U.S. Midwest. PhD diss., University of Missouri. Retrieved from https://mospace. umsystem.edu/xmlui/handle/10355/66184

Ransom, C. J., Kitchen, N. R., Camberato, J. J., Carter, P. R., Ferguson, R. B., Fernandez, F. G., ... Shanahan, J. F. (2019). Statistical and machine learning methods evaluated for incorporating soil and weather into corn nitrogen recommendations. Computers and Electronic in Agriculture, 164, 104872. https://doi.org/10.1016/ j.compag.2019.104872

Rochette, P., \& Gregorich, E. G. (1998). Dynamics of soil microbial biomass $\mathrm{C}$, soluble organic $\mathrm{C}$ and $\mathrm{CO}_{2}$ evolution after three years of manure application. Canadian Journal of Soil Science, 78, 283-290.
Russell, J. S. (1963). Nitrogen content of wheat grain as an indication of potential yield response to nitrogen fertilizer. Australian Journal of Experimental Agriculture and Animal Husbandry, 3, 319-325. https://doi.org/10.1071/EA9630319

Scharf, P. C., Kitchen, N. R., Sudduth, K. A., Davis, J. G., Hubbard, V. C., \& Lory, J. A. (2005). Field-scale variability in optimal nitrogen fertilizer rate for corn. Agronomy Journal, 97, 452-461. https://doi. org/10.2134/agronj2005.0452

Shields, J. A., Paul, E. A., \& Lowe, W. E. (1974). Factors influencing the stability of labeled microbial materials in soils. Soil Biology \& Biochemistry, 6, 31-37.

Singh, G., Schoonover, J. E., Williard, K. W. J., Kaur, G., \& Crim, J. (2018). Carbon and nitrogen pools in deep soil horizons at different landscape positions. Soil Science Society of America Journal, 82, 1512-1525. https://doi.org/10.2136/sssaj2018.03.0092

Shapiro, C. A., \& Wortman, C. S. (2006). Corn response to nitrogen rate, row spacing, and plant density in eastern Nebraska. Agronomy Journal, 98, 529-535. https://doi.org/10.2134/ agronj2005.0137

Soil Science Society of America. (1997). Glossary of Soil science terms. Madison, WI: SSSA.

Stanford, G., \& Smith, S. J. (1972). Nitrogen mineralization potentials of soils. Soil Science Society of America Proceedings, 36, 465-472. https://doi.org/10.2136/sssaj1972.03615995003600030029x

Stanford, G., \& Smith, S. J. (1978). Oxidative release of potentially mineralizable soil nitrogen by acid permanganate extraction. Soil Science, 126, 210-218.

Stecker, J. A., Buchholz, D. D., Hanson, R. G., Wollenhaupt, N. C., \& McVay, K. A. (1995). Tillage and rotation effects on corn yield response to fertilizer nitrogen on Aqualf soils. Agronomy Journal, 87, 409-415. https://doi.org/10.2134/agronj1995. $00021962008700030004 x$

Sylvia, D. M., Fuhrmann, J. J., Hartel, P. G., \& Zuberer, D. A. (2005). Principles and applications of soil microbiology (2nd Ed.) Essex, England: Pearson Education Inc.

Triplett, G. G., Haghiri, F., \& van Doren, D. M. (1979). Plowing effect on corn yield response to $\mathrm{N}$ following alfalfa. Agronomy Journal, 71, 801-803. https://doi.org/10.2134/agronj1979. $00021962007100050023 \mathrm{x}$

Tremblay, N., Bouroubi, Y. M., Belec, C., Mullen, R. W., Kitchen, N. R., Thomason, W. E., ... Ortiz-Monasterio, I. (2012). Corn response to nitrogen is influenced by soil texture and weather. Agronomy Journal, 104, 1658-1671. https://doi.org/10.2134/agronj2012.0184

Vanotti, M. B., \& Bundy, L. G. (1994). Corn nitrogen recommendations based on yield response data. Journal of Production Agriculture, 7, 249-256. https://doi.org/10.2134/jpal1994.0249

Wade, J., Culman, S. W., Hurisso, T., \& Horwath, W. R. (2018). Sources of variability that compromise mineralizable carbon as a soil health indicator. Soil Science Society of America Journal, 82, 243-252. https://doi.org/10.2136/sssaj2017.03.0105

Weil, R. R., Islam, K. R., Stine, M. A., Gruver, J. B., \& Samson-Liebig, S. E. (2003). Estimating active carbon for soil quality assessment: A simplified method for laboratory and field use. American Journal of Alternative Agriculture, 18, 3-17.

Weil, R. R., \& Brady, N. C. (2015). The nature and property of soils (15th ed.). Essex, England: Pearson Education Limited.

Williams, J. D., Cozier, C. R., White, J. G., Heiniger, R. W., Sripada, R. R., \& Crouse, D. A. (2007). Illinois soil nitrogen test predicts southeastern U.S. corn economic optimum nitrogen rates. Soil 
Science Society of America Journal, 71, 735-744. https://doi.org/10. 2136/sssaj2006.0135

Woods End Laboratories. (2016). Soil $\mathrm{CO}_{2}$-burst official Solvita instructions. Version 2016/1 updated for DCR Model 700.6. Mt Vernon, ME: Woods End, Laboratories.

Yost, M., Veum, K., Kitchen, N. R., Camberato, J., Carter, P., Ferguson, R., ... Sawyer, J. (2018). Evaluation of the Haney Soil Health Nutrient Tool for corn nitrogen recommendations across eight Midwest states. Journal of Soil and Water Conservation Society, 73, 587-592. https://doi.org/10.2489/jswc.73.5.587

Zibilske, L. (1994). Carbon mineralization. In R. W. Weaver et al. (Eds.) Methods of soil analysis: Part 2. Microbiological and biochemical properties. Madison, WI: SSSA.
SUPPORTING INFORMATION

Additional supporting information may be found online in the Supporting Information section at the end of the article.

How to cite this article: Bean GM, Kitchen NR, Veum KS, et al. Relating four-day soil respiration to corn nitrogen fertilizer needs across 49 U.S. Midwest fields. Soil Sci. Soc. Am. J. 2020;84:1195-1208.

https://doi.org/10.1002/saj2.20091 